ISSN: 0213-2079 - ISSN electrónico: 2386-3889

DOI: https://doi.org/10.14201/shhmo2020422115143

\title{
CONTRABANDO, NEGOCIOS Y DISCORDIAS ENTRE LOS MERCADERES DE MÉXICO Y LOS CARGADORES PENINSULARES, 1670-1711
}

\section{Contraband, Commerce and Disagreements between Merchants of Mexico and Spanish Shippers, 1670-1711}

\section{Guillermina DEL VALLE PAVÓN \\ Instituto de Investigaciones Dr. José María Luis Mora minadelvalle17@gmail.com}

Fecha de recepción: 11/09/2020

Fecha de aceptación: 20/10/2020

RESUMEN: El artículo examina la participación de los mercaderes de plata del consulado de la ciudad de México en el comercio Atlántico, de manera legal e ilícita, durante los años 1670 a 1711 . Se analiza el funcionamiento de una enorme red comercial integrada por grandes tratantes de México y Sevilla, virreyes, gobernadores, armadores, autoridades portuarias, entre otros. Se muestra la participación de los mercaderes de México en la Carrera de Indias como encomenderos de las casas de comercio de Sevilla y Cádiz, y, cómo el notable aumento en el abasto de géneros europeos y asiáticos dio lugar a que entraran en antagonismo con los flotistas para establecer los precios de las mercancías. Por último, se expone cómo algunos flotistas se establecieron en la ciudad de México, se incorporaron al consulado y llegaron a ser sus representantes.

Palabras clave: contrabando; comercio Atlántico; Carrera de Indias; consulados; mercaderes; ciudad de México.

1. Agradezco los valiosos comentarios que hicieron a este artículo Francisco Andújar, Luis Gerardo Morales y Antonio Ibarra, los cuales me permitieron mejorarlo. 
ABSTRACT: This article analyzes the participation of the silver merchants of Mexico City in the Atlantic trade, legal and illegal, between the years 1670 to 1711 . It examines how they practiced clandestine trafficking in alliance with the viceroys and through networks of complicity with the authorities of the port of Veracruz and the ship's captains. It shows their participation in the convoy system of the Spanish treasure fleet as messengers (encomenderos) for the trading houses of Seville and Cadiz, and how the saturation of the narrow markets of New Spain, due to the notable increase in the supply of European and Asian goods, led them to enter into antagonism with the shipping companies for establishing the prices of the goods. Finally, it is explained how some ship owners established themselves in Mexico City, joined the consulate and became its representatives.

Keywords: smuggling; Atlantic trade; convoy system of the Spanish treasure fleet; merchant guilds; merchants; Mexico City.

En el último tercio del siglo XVII, los mercaderes del consulado de la ciudad de México adquirieron el control sobre la circulación de la plata novohispana, que era uno de los principales medios de pago a nivel global. La concentración del preciado metal y su capacidad para otorgar crédito les permitió dominar los circuitos comerciales oficiales y clandestinos que articulaban los mercados de Nueva España con Europa, Filipinas, los principales puertos de la Mar del Sur y del Caribe. El presente artículo tiene el propósito de analizar la forma en que los mercaderes en cuestión participaron en el tráfico Atlántico, legal e ilícito, que se desarrolló durante los años 1670 a 1711. El estudio empieza con el año en que inició el incremento sostenido de la producción de plata en Nueva España y, en consecuencia, aumentó notablemente la demanda de bienes externos, y concluye con el fin de la administración del virrey duque de Alburquerque, cuando empezó a cambiar la política de los Borbones con respecto al tráfico clandestino. En estos años, el margen de maniobra de dichos actores económicos se amplió, como consecuencia de la mayor disponibilidad de plata, así como del aumento notable del contrabando en la Carrera de Indias y del que realizaban los rivales de la corona desde las islas de las Antillas. Se trata de una época en que Nueva España ostentó una gran autonomía económica, tanto por el poder financiero de la oligarquía mercantil de la ciudad de México, como por la debilidad de la monarquía para hacerse obedecer y afrontar la rivalidad de las principales potencias europeas.

La organización del tráfico entre la Vieja y la Nueva España a través de flotas que realizaban expediciones periódicas entre Sevilla, Cádiz y Veracruz, tuvo como

Ediciones Universidad de Salamanca / @®@@ Stud. his., H. ${ }^{a}$ mod., 42, n. 2 (2020), pp. 115-143 
propósito reducir los riesgos de la navegación y asegurar el cobro de derechos fiscales. Como sabemos, la monarquía hispánica estableció un régimen de monopolio que pretendía excluir al resto de los reinos europeos de los mercados de Hispanoamérica. Sin embargo, en los hechos, no logró su objetivo. En el transcurso del siglo XVII, las manufacturas europeas desplazaron progresivamente a las españolas, mientras que las potencias rivales realizaron un contrabando cada vez mayor. De acuerdo con la historiografía especializada, el tráfico ilícito en la Carrera de Indias se realizaba tanto por los cargadores andaluces, como por los franceses, ingleses, holandeses y otros extranjeros establecidos en Cádiz, que comerciaban a través de prestanombres españoles (García-Fuentes, 1980: 104-109; Bustos Rodríguez, 2005:138-184, 355-372; Martínez Ruiz, 2011: 177-202; Díaz Blanco, 2012: 254-266 y 2018). Por otra parte, el comercio intérlope que los enemigos europeos practicaban desde las Antillas se incrementó notablemente a raíz de que adquirieron derechos territoriales. El contrabando que se practicaba desde Martinica, Saint-Domingue (actualmente Haití) (Gutiérrez Lorenzo, 1993: 88-89), Jamaica y Curazao, creció notablemente a partir de la década de 1680, cuando dichas posesiones se transformaron en centros de acopio y redistribución de mercancías (Macleod, 1990, v. 2: 76-79; Romano, 2004: 282-284; Martínez Ruiz: 178-180). Durante la Guerra de Sucesión Dinástica (1701-1713) dichos intercambios crecieron más, en particular el que realizaban los comerciantes franceses. Solo así se explican las estimaciones de Morineau sobre el espectacular incremento que presentaron las remesas de plata americana a los principales puertos de Europa, a partir de la década de 1660 (Morineau, 1985). El monopolio mercantil generaba una fuga creciente de caudales hacia las economías rivales, mientras que por la vía del contrabando se abría paso la hegemonía británica en el Atlántico.

El aumento en enormes proporciones del tráfico clandestino en la Carrera de Indias fue propiciado, en gran medida, por los cambios institucionales introducidos a causa de las necesidades pecuniarias de la corona. Acuciada por «la ocultación y [los] fraudes que se cometían», en 1660, reformó el derecho de avería, que sostenía la organización y resguardo de las flotas. Eliminó el cobro de dicho gravamen, así como el registro de la plata y los géneros en las flotas, y repartió el costo de la habilitación y defensa de los convoyes de la Carrera entre las comunidades mercantiles de Perú, Nueva España y Nueva Granada ${ }^{2}$. Este proyecto no tuvo el éxito que se esperaba, por lo que se recurrió a la venta de los cargos de la alta oficialidad de la armada y los navíos de las flotas de Indias, fenómeno que propició su participación en el tráfico clandestino de manera sistemática (Díaz Blanco, 2015:117-138; Andújar Castillo,

2. El soberano reservó la contribución de los andaluces para las contingencias Real cédula del 28 de marzo de 1660. Archivo General de la Nación [en adelante AGN], Archivo Histórico de Hacienda [en adelante AHH], 599-3. 


\section{GUILLERMINA DEL VALLE PAVÓN \\ CONTRABANDO, NEGOCIOS Y DISCORDIAS ENTRE LOS MERCADERES DE MÉXICO Y LOS CARGADORES PENINSULARES, 1670-1711}

2016: 265-286). Diversos historiadores coinciden en que la supresión del pago de los derechos de avería y almojarifazgo ${ }^{3}$, y del registro de las cargas favorecieron el contrabando (Oliva Melgar, 2005: 49-73; Delgado Rivas: 2007: 56-71). Mientras que en Nueva España, la producción argentífera presentó un aumento sostenido, a partir de 1670, el cual generó una demanda creciente de géneros europeos y asiáticos, que fue satisfecha por los canales legales y clandestinos (Bakewell, 1976: 259-312). Estos también eran vendidos a los peruanos que, atraídos por sus bajos precios, acudían en sus propios navíos a Veracruz, Acapulco, otros puertos no habilitados, para intercambiarlos por cacao de Guayaquil, plata, azogue de contrabando, y algunos otros productos (Gutiérrez Lorenzo, 1993: 372-375; García de León, 2011: 619-620).

Para llevar a cabo nuestro objetivo, dividimos el ensayo en cinco apartados. En primer lugar, analizamos la forma en que los mercaderes de plata de la ciudad de México participaron en el contrabando de bienes europeos, mediante la articulación de entramados relacionales que involucraron a personajes notables de la monarquía y a los virreyes. A continuación, revisamos las redes de complicidades que establecieron dichos actores económicos con las autoridades del puerto de Veracruz y los capitanes de navíos. Más adelante, examinamos su papel como encomenderos por comisión de las casas de comercio de Sevilla y Cádiz. Asimismo, mostramos cómo el sobre abasto de los estrechos mercados novohispanos, debido al notable aumento en el abasto de géneros europeos y asiáticos, dio lugar al antagonismo entre los mercaderes de México y los cargadores flotistas por establecer los precios de las mercancías. Por último, se expone cómo algunos flotistas que se establecían en la ciudad de México, se incorporaban al consulado y llegaban a ser sus representantes. Para ello, estudiamos la trayectoria de un consignatario, cuyo caso es representativo de un $6 \%$ de los mercaderes que fueron cónsules del cuerpo mercantil en el periodo estudiado.

\section{LOS MERCADERES DE MÉXICO EN EL TRÁFICO ILÍCITO}

En este ensayo sostenemos que el tráfico ilícito que se realizaba en los convoyes del Atlántico y por los enemigos de la corona establecidos en las Antillas, fue posible por la participación de los mercaderes de la ciudad de México, que concentraban la mayor parte de la plata que se producía en Nueva España. Para disponer del metal blanco dichos actores económicos habilitaban a los productores mineros,

3. Díaz Blanco (2018) expuso como la Universidad de cargadores de Indias abandonó la administracion de la avería en 1655, debido a los conflictos que desde décadas atrás había entre el cuerpo mercantil y la real Hacienda a causa a las presiones que Felipe IV había ejercido sobre la Carrera como consecuencia de las guerras y la inflación.

Ediciones Universidad de Salamanca / @®@@ Stud. his., H. ${ }^{a}$ mod., 42, n. 2 (2020), pp. 115-143 
compraban plata de rescate $e^{4}$ en grandes cantidades y recibían depósitos a interés de los principales rentistas que residían en la capital del virreinato. Con el fin de hacer su negocio más redituable, destinaban al tráfico clandestino el metal que no había pagado derechos o solo había contribuido con el diezmo, gravamen que estaba reservado a los mineros. En 1641, el visitador Juan de Palafox y Mendoza, luego de descubrir un fraude en la real caja de Zacatecas por 100,000 pesos, había concluido que «quintos y diezmos del oro y la plata no llegan enteros al rey, porque los minerales recién extraídos no se quintan en la boca de la mina, sino en las cajas de cada partido, y en el camino se sustraen grandes cantidades» (González González y Gutiérrez Rodríguez, p. 87). Diez años después, en 1651, se descubrió que se habían despachado al puerto de Veracruz 108.000 pesos en barras de rescate y del diezmo, ocultas en cajones de chocolate, para embarcarlos en los navíos de la flota. Dichos cajones iban destinados a Don García de Haro Sotomayor y Guzmán, conde de Castrillo, quien fue presidente del Consejo de Indias de 1635 a 1665 y regente del reino en varias ocasiones por ausencia de Felipe IV. A pesar de las diligencias que se practicaron y de que se sometió a tormento al arriero que había conducido la plata, no aparecieron sus propietarios (Guijo, 1952: 186-187, 191-192).

A mediados del siglo XVII se calculaba que la extracción de plata que no había pagado derechos representaba una tercera parte de la producción del virreinato, fenómeno que se incrementó conforme pasaron los años (Lang, 1977: 24, 25). En las últimas décadas del siglo XVII, el papel de los mercaderes de México en el crecimiento de la minería fue fundamental porque garantizaron el abasto de azogue mediante su financiamiento (Valle Pavón, 2011: 565-598 y 2020: 141-146). Entonces, también tuvieron mayor participación en el contrabando de efectos europeos y asiáticos, de esclavos, así como de cacao de Venezuela y Guayaquil, azogue, vinos y otros productos peruanos (Gutiérrez Lorenzo, 1993: 364-366; García de León, 2011: 619-620). Para realizar el comercio legal e ilícito, tejieron complejas redes oligárquicas de negocios, estructuradas por fuertes vínculos de confianza basadas en el parentesco, el paisanaje, el compadrazgo y la amistad. No obstante, como veremos a continuación, la realización de dichos ilícitos también fue posible porque contaban con el apoyo de los virreyes, así como de las autoridades de Veracruz y Acapulco, que eran los únicos puertos habilitados del virreinato.

Contamos con una fuente de la época que desnuda las prácticas ilegales en Nueva España, en el valioso testimonio de Francisco de Seijas y Lobera. Originario de Galicia, en su obra escribió que había sido capitán de varios navíos, comerciante en el norte de Europa y había practicado el corso, por lo que conocían las prácticas

4. Se llamaba plata del rescate al metal refinado, que no había pagado derechos, el cual se cobraba a los trabajadores de las minas, a los pequeños mineros y refinadores (Serrano Hernández, 2018: 411, 461). 
mercantiles legales e ilícitas. Al inicio de la década de 1690, había adquirido en la corte real el nombramiento de alcalde mayor de Tacuba, jurisdicción ubicada en el entorno de la ciudad de México. Antes de partir rumbo a Nueva España, el Consejo de Indias le ordenó que le enviara «informes secretos sobre el gobierno y la situación de las Indias», lo que explica, en parte, el origen de su destacada obra. Sin embargo, cuando llegó a México, a fines de 1692, el virrey Gaspar de Sandoval Silva y Mendoza, conde de Galve, que gobernó Nueva España de 1688-1696, inconforme porque la designación del monarca había limitado su prerrogativa para beneficiar dicha plaza a uno de sus paniaguados, puso obstáculos para que tomara posesión de su cargo y, poco después de haberlo hecho, fue encarcelado en varias ocasiones con diversos motivos, hasta que finalmente fue desterrado. El cambio de dinastía dio oportunidad a Seijas para escribir su estudio sobre el gobierno del virreinato, en el que denunció las prácticas ilícitas de los virreyes y formuló un conjunto de propuestas para mejorar el gobierno de Indias (Pérez-Mallaína, 1986: 7-27).

Muy probablemente, resentido por el mal trato que le había dado el conde de Galve, Seijas y Lobera denunció que «los virreyes», «apenas llegan a tomar posesión [...] con las providencias que dejan dispuestas con los mercaderes de la Andalucía, hacen poner en México dos o más almacenes de mercancías en negociantes de su mayor confianza para que las vendan por cuenta del Virrey, y como estos almacenes nadie se atreve a sindicarlos, se venden de ordinario en ellos los mayores contrabandos que se introducen en aquellas provincias». Asimismo, sostuvo que «un virrey», tenía sus propias embarcaciones «en cabeza de sus confidentes», la cual había enviado en secreto a Cádiz en busca de grandes cantidades de géneros, y valiéndose de «ministros de su confidencia» y «mercaderes factores suyos», las había descargado al norte de Tampico, en donde, además, había recibido mercancías de dos fragatas extranjeras. El mismo virrey, enviaba sus propios navíos a Jamaica y Curazao, permitía que las fragatas de los holandeses arribaran a Veracruz y tenía otro navío que abastecía de géneros extranjeros al Perú y traía azogue de Huancavelica de contrabando (Seijas y Lobera, 1986: 312-314, 508). Es probable que el conde vendiera dicho mercurio a los mercaderes de plata, quienes, como habilitadores de los mineros, solían adquirir el que entraba al virreinato de manera clandestina.

Para realizar sus negocios, el conde estableció estrechas relaciones con algunos de los principales mercaderes de plata que se ubicaban a la cabeza del consulado de México. Esta alianza permitió garantizar el financiamiento del suministro de azogue de Perú, Europa y China, y que el cuerpo mercantil se hiciera cargo de la administración del derecho de alcabalas (Valle Pavón, 2020: 141-148). El conde de Galve se vinculó de manera especial con Luis Sánchez de Tagle, dueño de uno de los tres bancos de plata de la época, que fue prior del consulado en el bienio 1691-1692. Es posible que don Luis fuera designado para dicho ministerio por influencia del

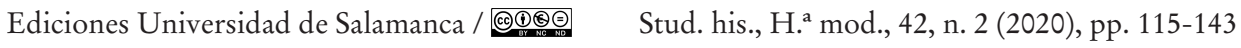


mismo virrey ${ }^{5}$, aunque contaba con méritos propios y tenía una importante red al interior del consulado (Valle Pavón, 2020: 149-158 y 2011: 569-570, 576-579, 588-591). Don Luis, quien labraba el metal que adquirían él y otros mercaderes consulares, fue nombrado por Galve amonedador oficial de las platas del monarca. Es muy probable que fundiera el metal que había sido ensayado y gravado -cuya ley había sido probada- con la plata de rescate y del Perú que tenían menor grado de pureza, como solían hacer los mercaderes de la casa de moneda desde décadas atrás ${ }^{6}$. Sánchez de Tagle tenía una relación de clientela con el conde. En 1690, hizo un cuantioso préstamo al capitán Pedro Ibáñez de Leiva, caballero mayor del virrey, procurador general de Nueva España y alcalde mayor de Jicayánn. En el mismo año, se obligó por una gruesa suma como fiador de Fernando Manuel Bustamante y Bustillo, gentilhombre de Galve, para que comprara la gubernatura de Yucatán ${ }^{8}$.

De acuerdo con Seijas y Lobera, el virrey y los mercaderes del consulado de México utilizaban las tres fragatas de la Armada de Barlovento para introducir gran cantidad de bienes europeos de contrabando, cuando regresaban de llevar los situados a la Florida y las islas de Barlovento (Seijas y Lobera, 1986: 319-521) Es muy probable que Sánchez de Tagle hubiera estado involucrado en dichos intercambios comerciales ilícitos, ya que su sobrino Domingo Ruiz de Tagle se desempeñó como alférez en dicha Armada durante poco más de siete años, entre 1687 y 1694 . Entonces debió haber constituido un apoyo fundamental para que su tío y el conde de Galve pudieran realizar el tráfico ilícito. Durante su administración, el conde puso especial empeño en impulsar la Armada de Barlovento y la defensa de las posesiones de las Antillas, muy probablemente guiado por sus intereses personales ${ }^{9}$.

El comercio por el Pacífico fue uno de los negocios más relevantes de Sánchez de Tagle, porque operaba con mayor autonomía y menos competencia. Don Luis traficaba bienes orientales con Filipinas, los cuales distribuía, junto con géneros europeos, en el virreinato, así como en los principales puertos del Caribe y la Mar del Sur, entre los que destacan los del Perú. El conde de Galve se involucró en el tráfico de contrabando de bienes orientales que realizaba Sánchez de Tagle con Fausto Cruzat y Góngora, quien había pagado 50.000 reales por su nombramiento como gobernador de Filipinas. Además, favoreció la reactivación del tráfico con los puertos

5. Sobre la ingerencia de los virreyes en la designación de los representantes del consulado, véase (Valle Pavón, 2003: 41-72).

6. Acerca de dichas prácticas, véase Hoberman 1998: 75-77.

7. Archivo General de Notarías de la ciudad de México [en adelante AGNCM], notario 379, Baltazar Morantes, vol. 2521, Año de 1690.

8. AGNCM, notario 379, Baltazar Morantes, vol. 2521, Año de 1690.

9. Certificación de los servicios hechos en Indias por el General Don Domingo Ruiz de Tagle, Secretaría del real Consejo de las Órdenes. AHN, Consejo de Órdenes, OM-Caballeros Alcántara, exp. 1340, año 1704. 
del Pacífico meridional, que estaba prohibido (Rosenmüller, 2008: 82; Valle Pavón, 2006: 30-31). Por los elevados rendimientos que generaba el comercio Pacífico, el virrey conde de Galve, muy probablemente en alianza con Fausto Cruzat, en 1696 decidió que Domingo Ruiz de Tagle dejara la Armada de Barlovento para reclutarlo como capitán de la guarnición de Filipinas. Al inicio de la década de 1670, Ruiz de Tagle había sido sargento mayor del Tercio de Navarra, bajo el mando de Cruzat y Góngora, y unos años después, ambos habían residido en el puerto de Cádiz (Rosenmüller, 2008: 163-164). Con la confianza que brindaba una larga amistad, Fausto Cruzar nombró a Ruiz de Tagle sargento mayor, en 1699, y en mayo de 1700 , junto con los capitulares de la ciudad de Manila, lo designó general de la nao capitana Nuestra Señora del Rosario, San Francisco Javier y Santa Rosa, para viajar al puerto de Acapulco ${ }^{10}$. En esta forma, uno de los mercaderes más acaudalados de la ciudad de México realizó lucrativos negocios ilícitos, en sociedad con el virrey de Nueva España y el gobernador de Filipinas.

En el juicio de residencia que se realizó al término del mandato del conde de Galve, el alcalde del crimen más antiguo de la real Audiencia lo acusó de haber realizado contrabando de bienes asiáticos y azogue peruano en la Armada del Callao, los navíos de azogue y otras embarcaciones. Sin embargo, los oficiales reales de Acapulco no apoyaron la denuncia, por lo que fue absuelto de dicho cargo (PérezMallaína, 1986: 73-74).

El conde de Galve se valió de testaferros para comerciar y practicó el tráfico ilícito en tan grandes proporciones para lucrar, aprovechando el enorme poder que detentaban los virreyes y la discrecionalidad con la que gobernaban. Galve, al igual que sus antecesores estaba protegido porque pertenecían a la alta nobleza castellana y tenía gran influencia en la corte de Madrid. Había sido favorito de los reyes y contaba con el sólido respaldo de su hermano, el duque del Infantado, que era Consejero de Estado, y de su suegro, el marqués de Villafranca, entonces virrey de Sicilia (Gutiérrez Lorenzo, 1993: 38-42; Andújar Castillo, 2019: 322-323). Además, en 1688, cuando había sido beneficiado con el nombramiento de representante del soberano en Nueva España por un periodo de tres años, le habían dado una cédula secreta que prorrogaba su mandato por otro trienio. De acuerdo con Francisco Andújar, dicha medida daba a los virreyes mayor libertad «para conseguir sus aprovechamientos y valerse de múltiples corruptelas con las que enriquecerse», al dejarlos exentos del juicio de residencia del primer periodo de gobierno (Andújar Castillo, 2019: 338-339) Galve salió indemne de su juicio de residencia, aun cuando Jerónimo Chacón, el alcalde del crimen de la Audiencia, presentó ante el juez de

10. Certificación de los servicios hechos en Indias del General Don Domingo Ruiz de Tagle, Secretaría del real Consejo de las Órdenes. AHN, Consejo de Órdenes, OM-Caballeros Alcántara, exp. 1340, año 1704. 
residencia un memorial que contenía muy graves acusaciones, varias de las cuales lo implicaban en el comercio ilícito. Sin embargo, este documento no fue admitido con el argumento de que se había presentado fuera de plazo. Es muy probable que en la decisión del juez de residencia haya pesado la influencia política que el conde tenía en la corte real (Pérez-Mallaína, 1986: 74-75; Gutiérrez Lorenzo, 1993: 105-106 y 171-188).

Con la llegada del primer monarca de la dinastía de los Borbones empezaron a cambiar las cosas. Durante la Guerra de Sucesión Dinástica, los franceses se esforzaron por dominar la carrera de Indias, al participar en instancias como la Junta de Restablecimiento de comercio. Su principal logro consistió en retrasar la partida de la flota hasta 1706, para favorecer el contrabando que realizaban sus compatriotas en Hispanoamérica. Dicho convoy fue custodiado por navíos de guerra galos, lo que fue aprovechado para realizar un intenso tráfico ilícito (Walker, 1979: 39-56, 75-79). En 1708 arribó a Veracruz la flota a cargo del comandante Andrés de Pez, quien remitió al Consejo de Indias una gravísima acusación contra el virrey Francisco Fernández de la Cueva Enríquez, duque de Alburquerque, el segundo miembro de dicho linaje que gobernó Nueva España. Denunció que, en los últimos tres años, había permitido la descarga de más de ochenta embarcaciones francesas, con la colaboración del gobernador y los oficiales reales del puerto. Además, había invertido más de medio millón de pesos en el comercio ilícito, con lo que pretendía «malograr» la feria de la flota, en cuyo tráfico clandestino había participado. Unos meses después, en 1709, el virrey dio autorización para comerciar al capitán de una fragata francesa que arribó a Veracruz, procedente de Burdeos, a pesar de la oposición del gobernador y los oficiales reales del puerto. El Consejo de Indias reprobó el proceder del duque y su fiscal manifestó que mientras los virreyes tomaran tales determinaciones, no podría limitarse el contrabando. Y al inicio de 1710 se repitieron las órdenes que reprobaban el contrabando, en las que se sostuvo que las justicias, gobernadores y oficiales reales de «las costas de uno y otro mar [...] son las más seguras escalas de tan perjudiciales comercios y los disimulan y se dan por desentendidos de ellos por su utilidad particular [...]» (Navarro García, 1979: 204-206).

En 1708, la flota de 1706 retornó al puerto de Pasajes en Guipúzcoa, con gran cantidad de plata sin registrar, lo que dio lugar a que se extendieran rumores sobre el tráfico clandestino que practicaban los franceses. Todo ello generó gran disgusto en el gobierno, por lo que el ministro de Guerra y Hacienda, en atención a la iniciativa del consulado de Sevilla, ordenó al secretario del Consejo de Indias realizar una investigación sobre la denuncia de contrabando presentada por Andrés de Pez. En las averiguaciones que realizó el oidor Félix González Agüero, a fines de 1709, se encontraron culpables a los mercaderes consulares, Luis y Jerónimo Monterde, a los comerciantes de Veracruz José de Aristegui y Francisco de Aguirre Gomendio, a los gobernadores Francisco Manso y Pedro Yrles, a dos oficiales reales y a los

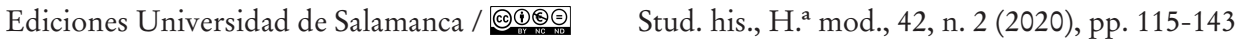


guardas del puerto, pero no hubo cargos contra el virrey. Aguirre Gomendio y los oficiales reales fueron arrestados, sin embargo, al igual que los otros mercaderes se acogieron al indulto que beneficiaba al erario regio. Luis y Jerónimo Monterde pagaron 40.000 pesos, Aguirre Gomendio 8.000 pesos y Aristegui 12.000 pesos. Este último consiguió que los autos se destruyeran, y se mandara guardar "perpetuo silencio» sobre el asunto (Navarro García, 1979: 205-208).

En el juicio de residencia del virrey Alburquerque, se puso especial atención a las denuncias relativas al contrabando que habían practicado 78 navíos franceses en Veracruz, entre 1702 y 1707. Sin embargo, los cargos no progresaron porque el duque argumentó que no era factible tener control sobre un puerto que favorecía las arribadas ilegales. Alburquerque salió absuelto porque no había pruebas, ni testigos en su contra, y había publicado los bandos contra del tráfico ilegal. No obstante, en 1711 se revisaron los informes presentados por el fiscal de la audiencia, González Agüero, quien destacó la corrupción de las autoridades. Sostuvo que los permisos que el duque había otorgado a los navíos galos para comerciar de manera ilícita le habían generado elevadas ganancias. Además, se había favorecido a los enemigos con las ventas de géneros de lana, especias y hojalata de procedencia inglesa y holandesa. El fiscal consideró que, si se habían impuesto penas a los súbditos por el tráfico ilícito, con mayor razón se debía hacerlo con el virrey, que también podía acogerse al indulto. El Consejo de Indias encargó al fiscal González Agüero que realizara una nueva investigación, al margen del juicio de residencia. Este recibió un documento anónimo en el que denunciaban las numerosas contravenciones realizadas por el duque, en el que se puso énfasis en los beneficios que había obtenido del contrabando y otras especulaciones de carácter comercial. Cuando Alburquerque regresó a España, en 1713, el monarca ordenó el embargo de su equipaje, en el que llevaba poco más de 103.000 pesos escudos, y su destierro de la corte. Luego de muchas súplicas y de que pagó un indulto por 700.000 pesos, en compensación por los tres millones de pesos que se supuso habría obtenido de la realización de negocios ilícitos, en 1716 se le permitió retornar del destierro (Navarro García, 1979: 206).

\section{LA COMPLICIDAD DE LAS AUTORIDADES PORTUARIAS Y LA OFICIALIDAD DE LAS FLOTAS}

Para realizar el tráfico ilícito, los mercaderes de México también contaban con la colaboración de los gobernadores, castellanos, oficiales y escribanos de las cajas reales de los puertos de Veracruz y Acapulco. En Veracruz, los castellanos, que estaban a cargo del fuerte de San Juan de Ulúa, permitían que las embarcaciones de los contrabandistas entraran al puerto, o desembarcaran en las costas aledañas. Asimismo, nombraban a los guardas de las cajas reales que vigilaban el desembarco

Ediciones Universidad de Salamanca / @®@@ Stud. his., H. ${ }^{a}$ mod., 42, n. 2 (2020), pp. 115-143 
de los navíos. De modo que, junto con los oficiales reales, encubrían las arribadas forzosas o «maliciosas» de las numerosas fragatas que desembarcaban sin licencia, así como de las mercancías que llegaban en las flotas fuera de registro. Los oficiales reales también se hacían cargo de las subastas de los productos que eran confiscados a los contrabandistas (Seijas y Lobera, 1986: 253, 516-518; Bertrand, 2011: 257-259; García de León, 2011: 619 y 663-665). Dichas autoridades recibían sobornos considerables o cobraban un porcentaje de las mercancías que se introducían de manera ilegal. En 1709, cuando se realizaron pesquisas sobre el tráfico ilícito que se realizaba en Veracruz, el virrey Alburquerque sostuvo que los oficiales reales eran culpables de contrabando, porque «obtenían el 12 o $16 \%$ de cuantos géneros se introducían y que habían concertado la adquisición de un barco entero de contrabando comprometiéndose a pagar el 100\% de su valor de compra» (Navarro García, 1979: 206). Unos años después, el oidor Félix González Agüero, que investigaba sobre el contrabando realizado con la participación del mismo virrey, un comerciante de Veracruz confesó haber sobornado a los gobernadores y oficiales reales del puerto con 89.000 pesos (Navarro García, 1979: 208-209).

Se ha calculado que, del total de las mercancías introducidas por la aduana del puerto de Veracruz, ingresaban de contrabando entre la mitad y las dos terceras partes (García de León, 2011: 617). Para los mercaderes de plata del consulado era muy importante integrar a sus redes de negocios a un oficial real de Veracruz, por lo que recurrían a diversas estrategias para obtener su respaldo en el tráfico ilegal. Algunos otorgaban crédito a dichos oficiales para que compraran sus cargos o pagaran las fianzas que les exigía el real erario (Hoberman, 1991: 154, 174-176, 180). Otros conseguían su colaboración mediante la concesión de préstamos en dinero, a plazos mayores de los que solían otorgar ${ }^{11}$. Por la importancia comercial que tenía el puerto, parientes de destacados miembros del consulado residían en él y eran miembros del cabildo, por lo que podían tener influencia sobre el castellano y los oficiales de la caja real. Como ejemplo tenemos a Joaquín de Zavaleta, cónsul en 1699 y prior en 1710-1711, quien tenía un familiar llamado José de Zavaleta, que fue regidor y alcalde ordinario de Veracruz y arrendó la recaudación de las alcabalas de su jurisdicción cuando menos de 1704 a 1722. Don Joaquín se casó con una hermana de Francisco Antonio de Medina Picazo, tesorero de la Casa de moneda, cuya esposa era hija del tesorero de la caja real de Veracruz (Bertrand, 2011: 237-239; Valle Pavón, 2011: 587).

Otro caso fue el Luis y Jerónimo de Monterde y Antillón, que fueron cónsules del tribunal mercantil, el primero, en 1705, y el segundo, en 1712-1713. Los hermanos

11. António Fernández Jubera, en 1680 , otorgó un préstamo cuantioso al Juez contador propietario de la real Hacienda y caja del puerto de Acapulco, con la garantía de su salario, el cual podía embargar, y otro por un monto menor y a un plazo más corto, al escribano mayor de la real hacienda y la ciudad. AGNCM, notario 379, Baltazar Morantes, Vol. 2511, Año de 1680.

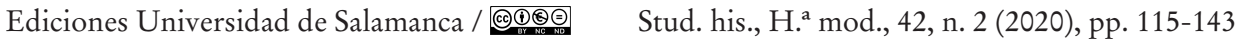


llegaron a Veracruz en 1680, con su pariente Juan Antonio de Peredo y Santurce (Sanchíz y Conde, 2005: 97-98), que había sido beneficiado con el cargo de general de la Armada de Barlovento ${ }^{12}$, en la que Luis y Jerónimo estuvieron empleados, cuando menos, durante trece años. Como vimos en dicha escuadra se realizaba el comercio clandestino cuando se llevaba el situado a Florida y los espacios de las Antillas. Luis se casó, hacia 1689, con la hija del alférez del Castillo de San Juan de Ulúa y alcalde ordinario de Veracruz, lo que le había permitido afianzar sus negocios ilícitos (Sanchíz y Conde, 2005: 97-99). Posteriormente ambos formaron parte del consulado y fueron aliados del virrey duque de Alburquerque. Jerónimo ocupó el cargo de cónsul en 1705, a petición del virrey, y este lo nombró en 1707 gobernador del Estado del marquesado del Valle, luego de nominarlo, junto con su hermano para que recibieran el hábito de la orden de Santiago (Valle Pavón, 2020: 162). En 1708 fueron acusados por uno de los oidores de la audiencia de traficar con ingleses y holandeses (Goyas Mejía, 2011, p. 62). Y en la investigación que se realizó al concluir el mandato del virrey duque de Alburquerque, se descubrió que habían estado involucrados en el contrabando que este había realizado (Navarro García, 1979: 210-214).

Por otra parte, en el contrabando que se realizaba en la Carrera de Indias, era indispensable la participación de los generales, almirantes, maestres de plata y capitanes de los navíos de las flotas y las armadas que las custodiaban. Los requerimientos financieros de la corona la habían llevado a proveer los cargos mencionados a cambio del otorgamiento de un donativo y un préstamo para financiar el apresto y los bastimentos de las flotas. En el caso de Nueva España, los caudales adelantados y sus intereses se restituían mediante el otorgamiento de libranzas que se saldaban en las reales cajas de Veracruz o la ciudad de México. Algunos candidatos se hicieron cargo de construir un navío para la flota con el propósito de recibir su nombramiento. Los cargos de general y almirante de las escuadras llegaron a superar los 100.000 pesos. De acuerdo con Francisco Andújar, el precio de los oficios dependía del prestigio que otorgaban, el plazo de la concesión y el salario, así como de los ilícitos que permitían realizar (Andújar Castillo, 2016: 265-286). Así, quienes invertían elevadas sumas en el beneficio de sus nombramientos los hacían rentables mediante su participación en el comercio ilegal, lo que les permitió acumular grandes fortunas.

Los oficiales de alto rango de la Armada y las flotas de Indias estaban estrechamente ligados con los cargadores del consulado de Sevilla. Un ejemplo ilustrativo es el de Gabriel de Curucelaegui, quien hizo carrera en la Armada de la flota de Indias y fue miembro del tribunal mercantil de Sevilla. El marino pertenecía a un poderoso linaje de mercaderes y compradores de metales preciosos, cuyos miembros seguramente lo apoyaron para la compra de sus cargos, lo que debió haber redituado con creces al negocio familiar. Otros candidatos, para los que no resultaba fácil disponer

12. Archivo General de Indias [en adelante AGI], Indiferente, 2516, L. 3.

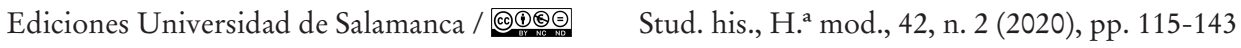


de elevados capitales, solicitaban el crédito de personas acaudaladas, entre las que debieron haberse distinguido los cargadores de la Universidad de Sevilla y las casas extranjeras de comercio establecidas en Cádiz (Andújar Castillo, 2018: 239-261). Es muy probable que esto sucediera con quienes aspiraban a los nombramientos de menor jerarquía, como los capitanes y maestres de plata que podían pagar por sus cargos entre 6.000 y 12.000 pesos, de los cuales otorgaban en préstamo hasta un 60\% y el resto como donativo (Andújar Castillo, 2016: 135-156).

Para realizar el contrabando era fundamental la connivencia con los capitanes y maestres de navíos que transportaban y estaban a cargo de las mercancías. Cuando arribaban a la bahía de Cádiz, dichos oficiales hacían posible el transbordo de los metales preciosos embarcados en Veracruz sin registrar, a los navíos extranjeros, muchas veces con la complicidad de las autoridades (Girard, 2006: 392-400). Para introducir las mercancías de contrabando que llevaban la flotas a Veracruz se recurría a estrategias similares. En 1689, el capitán del navío «Nuestra Señora de Regla, San José y las Ánimas», que hacía la travesía bajo el amparo de la flota a cargo del conde de Villanueva, desembarcó en La Habana un valioso cargamento que llevaba fuera de registro. Un comprador de plata de Sevilla lo había remitido con instrucciones de que se vendieran en Veracruz antes de la llegada de la flota. En este caso, los contrabandistas fueron descubiertos y la carga fue decomisada (Gutiérrez Lorenzo, 1993: 88). También es posible que cuando los navíos de la flota arribaban en Santo Domingo para proveerse de agua potable, aprovecharan para desembarcar las mercancías que llevaban de contrabando para después transportarlas de manera subrepticia al puerto de Veracruz.

\section{LOS ENCOMENDEROS DE LOS PENINSULARES}

Los mercaderes consulares de la capital novohispana participaban en la Carrera de Indias de dos maneras. Por una parte, operaban como encomenderos de las casas de comercio de Cádiz y Sevilla, y por otra, adquirían de manera directa las mercancías de los peninsulares que arribaban en las flotas. Cuando fungían como agentes de los castellanos, les solicitaban los artículos de mayor demanda. Los recibían en Veracruz por medio de un apoderado y se encargaban de venderlos a cambio de una comisión del 4 o $5 \%$, a la que agregaban otros beneficios. La ventaja de operar como encomenderos radicaba en que no arriesgaban sus caudales en la peligrosa travesía por el Atlántico y estaban a salvo de las confiscaciones que ejecutaba el rey en situaciones de emergencia. Los vínculos entre los mercaderes de México y los cargadores españoles se basaban en la colaboración y la confianza, ya que la mayoría de los contratantes solían ser familiares, paisanos o amigos. Los principales productos que recibían eran: gran infinidad de textiles europeos, cera, papel, acero y hierro vasco, éstos últimos, insumos básicos para la producción argentífera (Huerta,

Ediciones Universidad de Salamanca / @®@@ Stud. his., H. ${ }^{a}$ mod., 42, n. 2 (2020), pp. 115-143 
2007: 95, 96, 107). Los tratantes de la capital del virreinato pagaban con plata en moneda y en barras, principalmente y, en mucha menor medida con tintes (grana, añil y palo de tinte), cueros y cacao de Guayaquil. Es muy probable que gran parte de los géneros europeos que se introducían de contrabando y que se pagaran con plata de rescate y del diezmo.

Tenemos algunos ejemplos representativos sobre la participación de los mercaderes de México como encomenderos. Uno de ellos fue Domingo de Larrea, que fue prior en (1686-1687), operó como intermediario de su primo Andrés Martínez de Murguía ${ }^{13}$ y de Francisco Sáenz de Zuazo, ambos residentes en Cádiz. José de la Riva, que desempeñó el oficio de cónsul (1693-1694), fue apoderado de dichos comerciantes, quienes también abastecían a Dámaso de Zaldívar, que fue prior (1693-1695) y a José de Retes Largacha, entre otros miembros del consulado.

Por otra parte, Ramón de Torrezar, quien fue prior de la Universidad de cargadores a Indias de 1696 a 1702, envió a Luis Sánchez de Tagle, aceite y aguardiente por parte del consulado, y acero, por su propia cuenta y la de otro cargador, con el propósito de que los vendiera y le remitiera el producto correspondiente ${ }^{14}$. Es posible que estas encomiendas fueran excepcionales, ya que en esos años los comerciantes que se ubicaban a la cabeza de los cuerpos mercantiles de Sevilla y México colaboraron para financiar las compras de azogue de Almadén, con el fin de asegurar que no faltara el metal líquido para el beneficio de las minas de Nueva España (Valle Pavón, 2020: 141-146). Esta circunstancia, los pudo haber acercado y conducido a realizar dichas contrataciones.

Otro caso interesante es el de Alonso Dávalos Bracamonte, quien fue cónsul (1689-1690) y prior (1704-1706), así como un exitoso tratante de bienes europeos. En 1679, el mercader constituyó con su suegra una compañía para el trato de mercaderías, que renegociaron en 1680, cuando contaba con un capital de poco más de 98.000 pesos, de los que Dávalos Bracamonte obligó a pagar cerca de 74.000 pesos $^{15}$. Los cargadores peninsulares con los que operaba don Alonso le remitían los bienes europeos para que los vendiera por comisión a través de la oficialidad y la tripulación de los navíos de la flota. En 1680, otorgó un poder a un vecino y encomendero de Veracruz, para que recibiera de «los generales, almirantes, pilotos y marineros» los géneros y mercaderías que le enviaban de Castilla ${ }^{16}$. Dávalos Bracamonte, quien había nacido en Nueva Galicia y cuyos antepasados eran vizcaínos,

13. Juan Bautista de Larrea, sobrino de Domingo de Larrea, que fue gobernador de Nueva Vizcaya, en 1698, unos años después, propuso como su sucesor a su pariente Pedro Martínez de Murguía. (Huerta, 2007: 107).

14. Del Consulado de Sevilla a Lucas de Careaga o Luis Sánchez de Tagle. Sevilla, 6 de diciembre de 1703. AGI, México, Estado 38A, N.2, año 1703.

15. Archivo Moctezuma-Miravalle, (en adelante AMM), núm. 39.3, Leg. 1, exp. 3

16. Poder, 1680. AHNCM, escribano Fernando Veedor, notaría 687, v. 4624. 
tenía importantes vínculos con cargadores y funcionarios reales de Castilla. Ese mismo año, fue apoderado de Diego Ignacio de Córdoba, agente de negocios del Consejo de Indias ${ }^{17}$. Es probable que éste le ayudara a adquirir el oficio de chanciller mayor del tribunal de la Santa Cruzada, que negoció entre 1682 y 1695, por 110.000 pesos $^{18}$, así como el nombramiento de caballero de Santiago y el título de conde de Miravalle, los cuales recibió en 1690. Cuando Dávalos Bracamonte fungía como prior del consulado, en 1705, pudo proceder en contra de dos vecinos del puerto de Veracruz que le debían cerca de 15.000 pesos, que eran el resto de un adeudo mayor ${ }^{19}$. Esta deuda nos da una idea de la dimensión de los tratos que realizaba con mercaderías europeas.

Los mercaderes de plata también solían fungir como apoderados de los cargadores peninsulares para cobrar deudas y resolver otros problemas. En abril de 1690, un médico residente de Cádiz dio poder amplio al entonces prior Antonio Fernández Jubera para que en su representación cobrara, judicial y extrajudicialmente, de las personas en cuyo poder se encontraba el «neto procedido de una factura de mercaderías» que, según cuenta de España había importado 47.340 pesos. Dichos bienes se habían cargado en diferentes navíos de la flota que había zarpado de Cádiz en el verano de 1687, por cuenta y riesgo de doña Isabel de Maceda, quien la había traspasado al médico mencionado ${ }^{20}$. Esto confirma que en las flotas no solo invertían los tratantes, también lo hacían mujeres e individuos de diversas profesiones.

\section{4. «DISCORDIAS Y COMPETENCIAS» ENTRE NOVOHISPANOS Y FLOTISTAS}

Muchos de los tratantes de plata de la ciudad de México compraban al por mayor a los flotistas procedentes de Andalucía. Estos cargaban por su propia cuenta, o eran consignatarios, factores o comisionistas de los cargadores españoles. También podían ser prestanombres de los comerciantes franceses, ingleses, genoveses, holandeses, hamburgueses y flamencos establecidos en Cádiz (García-Fuentes, 1980: 104-109; Bernal, 1992: 53-57; Bustos Rodríguez, 2005: 138-184, 355-372; Díaz Blanco, 2012: 254-266). Su función consistía en hacer la travesía con las mercancías -que podían ser embarcadas de manera legal y clandestina-, recibirlas en Veracruz y venderlas en

17. Poder, México a 20 de diciembre de 1680. AGNCM, notario 379, Baltazar Morantes, Vol. 2511, Año de 1680.

18. AGS (Archivo General de Simancas), DGT, inv. 24, leg. 437. Agradezco a Francisco Andujar haberme proporcionado la ficha correspondiente.

19. Dávalos Bracamontes dio poder al alguacil mayor y regidor perpetuo de la villa de Córdoba para que presentara una carta de justicia. Poder, 1705. AGNCM, notario 15, Antonio de Avilés, vol. 100.

20. AGNCM, notario 120, José Esteban de Campos, Vol. 779, Año de 1690.

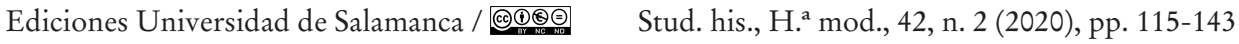


el virreinato. Para ello se internaban a las ciudades de México, Puebla y Oaxaca, en donde intercambiaban los bienes europeos, principalmente por plata novohispana y peruana, y en menor medida por grana cochinilla, añil de Guatemala, palo de tinte, cacao de Guayaquil o Guatemala bienes asiáticos, cueros y otros productos. Algunos flotistas revendían parte de estas mercaderías en el mismo virreinato. Asimismo, acudían a los principales reales mineros, muy probablemente para intercambiar los géneros de contrabando por el metal que no había sido gravado o solo había contribuido con el diezmo con el propósito de hacer más fructíferas sus negociaciones ${ }^{21}$. Uno de los oidores de la audiencia, comentó, en 1663, que algunos mineros iban a la ciudad de México para intercambiar la plata que no había pagado derechos con «los tratantes de las flotas de manera clandestina» (Bakewell, 1976: 254).

El abasto de textiles europeos a Nueva España por parte de las flotas, de manera legal e ilícita, empezó a crecer en la década de 1670 (García-Fuentes, 1980; Morineau, 1985), cuando se inició el incremento de la producción argentífera (Bakewell, 1976: 239, 259-304, 322-325; Stein y Stein, 2002: 148-149). Este fue posible debido al mejor suministro de azogue que permitía beneficiar los metales de baja ley. Los virreyes empezaron a comprar mercurio de Huancavelica, para paliar el desabasto del metal líquido procedente de las minas de Almadén, gracias al financiamiento de los mercaderes de México (Valle Pavón, 2011: 565-598 y 2020: 141-146). Las remisiones del azogue peruano reactivaron la navegación intervirreinal, a pesar de que se había prohibido de manera terminante a fines de la década de 1630. En 1670 también se dinamizó el tráfico con Filipinas, en donde se incrementó la oferta de sedas y otros bienes chinos, tanto por la necesidad que tenía el Imperio asiático de la plata americana, (después de perder el suministro de los japoneses), como por la estabilidad que siguió al fin de la lucha contra los poderes feudales (Prakash, 2001: 59-76). El mercado novohispano pudo asimilar las crecientes cantidades de géneros europeos y asiáticos porque los peruanos acudían a comprarlos a los puertos de Veracruz y Acapulco, atraídos por sus bajos precios. Al igual que en el comercio transatlántico, en el Pacífico no se acataba la normatividad restrictiva. Había un intenso tráfico de contrabando, basado en las complejas redes tejidas por los mercaderes de la ciudad de México que involucraban a las principales autoridades de Nueva España, Perú y Filipinas (Gutiérrez Lorenzo, 1993: 372, 373; Bonialian, «El Galeón», 2016, pp. 38-42).

El singular incremento en el suministro de textiles de Europa y Asia terminó con la estrategia de los cargadores andaluces de generar escasez en los mercados americanos con el propósito de imponer los precios más elevados. A fines de la década de 1660, los flotistas empezaron a tener problemas para vender en Nueva

21. Del Consulado de México al de Cádiz y a D. Pedro Cristóbal de Reinoso, México, 15 de noviembre de 1723. AGN, AHH, 2025; Representación del Consulado de México, 15 de mayo de 1725. AGN, AHH, 269-2. 
España los géneros europeos. Como el abasto que realizaban estaba basado en meras estimaciones acerca de la demanda de los consumidores, en 1670, la corona ordenó a los comandantes de los convoyes, que en cuanto llegaran a Veracruz mandaran a Sevilla noticias acerca de la escasez o abundancia de las mercaderías y sus precios, con el fin de preparar la carga del siguiente convoy ${ }^{22}$.

La gran oferta de los géneros asiáticos y europeos de contrabando, hacía poco atractiva la adquisición de las mercancías que llegaban en las flotas a precios mucho mayores. Por ello, el consulado de México trató de influir para que se espaciara su envío. En 1672, pidió al cuerpo mercantil de Sevilla que se esforzara por impedir la salida del convoy, porque la del año anterior había llevado una carga muy considerable y temía que los precios cayeran en perjuicio de ambos comercios. Como la Guerra franco-holandesa (1672-1678) había impedido el suministro de los tejidos europeos y a los cargadores no les convenía encontrarse con un mercado bien abastecido que los obligara a rebajar los precios, el consulado de Sevilla negoció con las autoridades reales que se retrasara un año el envío de la flota, y que en 1674 no se enviara, a cambio de lo cual otorgó al rey un donativo por 100.000 pesos. Cuando se preparaba la salida de la flota, en 1673, el consulado de México volvió a plantear al de Sevilla que no se habían podido vender los numerosos géneros que habían llevado los convoyes anteriores, pero la expedición no se pudo suspender (Lamikiz, 2011: 9; Díaz Blanco, 2012: 251). En adelante, la remisión de las flotas se tornó irregular, lo que favoreció aún más la competencia de precios entre las mercancías de contrabando y el acotado monopolio de la Carrera de Indias.

El gran abasto de bienes europeos y orientales agudizó los conflictos entre los flotistas y los tratantes de plata de la ciudad de México por el establecimiento de los precios de las mercancías. Los mercaderes de la capital del virreinato sabían que la mayor parte de los peninsulares no podían permanecer largos periodos en el virreinato porque tenían que regresar en el mismo convoy que habían llegado, entre otras razones, para saldar los créditos que habían contraído. Entonces se aprovechaban de esta situación para obligarlos a rebajar los precios de los géneros que ponían a la venta, al retrasar sus compras hasta que se anunciaba la partida de la flota. En 1716, el virrey duque de Linares atribuyó las «discordias y competencias» que se presentaban entre los flotistas y los comerciantes de México, a que los primeros «regularmente vienen con intención de llevarse, si pudieran, el reino, y los habitantes en la de resistirla, discurriendo que sitiándolos con la necesidad les han de obligar a que dejen la ropa al precio más ínfimo que pueden» ${ }^{23}$.

A finales de la década de 1670, la Universidad de Cargadores de Indias planteó que los comerciantes de México, una vez que conocían con todo detalle la calidad

22. Real cédula del 19 de junio de 1670. AGN, AHH, 599-3.

23. «Relación dada por el excmo. señor duque de Linares...», (Torre Villar 1991: 787-788).

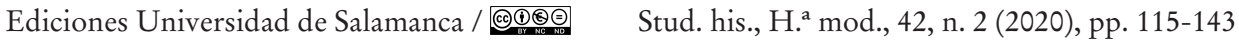


de las mercancías, maniobraban para «comprar [a] los precios que ellos quieren y confieren, deteniéndose en la compra y esperando a que la abundancia de un género obligue a venderlo al precio que ellos entre sí disponen, y en otros géneros proponiendo la tasa que quieren» ${ }^{24}$. Así podían pagar más por los productos que escaseaban, y dilatar sus compras hasta que los peninsulares redujeran los precios de los que abundaban. Por esta razón, para los flotistas era muy importante impedir que los mercaderes de la capital novohispana conocieran el contenido de las cargazones que pondrían a la venta. Desde 1665 la Universidad de cargadores de Sevilla solicitó al rey que el consulado de México, que tenía a su cargo la administración de la renta de alcabalas, no abriera y reconociera los fardos y cajones para cobrar el gravamen. El virrey, apoyó al cuerpo mercantil novohispano al manifestarse en contra de dicha medida, pero el monarca le pidió un informe sobre el asunto, con el parecer de la Junta de Hacienda, así como de otros administradores y conocedores del problema para que el Consejo de Indias tomara una resolución ${ }^{25}$.

No conocemos la resolución del monarca, pero a fines de la década de 1670, los diputados del comercio de España manifestaron al juez superintendente del ramo de alcabalas el grave perjuicio que les ocasionaba que sus envoltorios y cajones se registraran y reconocieran en la aduana de la ciudad de México. Los representantes de los flotistas lograron negociar un indulto para introducir cerrados sus fardos y cajones a cambio de una contribución de 12.000 pesos. En adelante, cada vez que llegaba un convoy, los peninsulares aportaban dicha suma para mantener la reserva sobre el contenido de los bultos y embalajes que introducían a la capital del virreinato. Esta medida adquirió mayor importancia a partir de 1694, año en que el consulado se hizo cargo de la administración de las alcabalas de la ciudad de México ${ }^{26}$.

Algunos flotistas no pudieron desenvolverse en un mercado en el que había aumentado la competencia de manera notable. Un comisionista sevillano, pobre y enfermo, declaró en 1681, que desde años atrás había venido a Nueva España como consignatario y con alguna hacienda propia que había obtenido a crédito. Se lamentó porque en su último viaje solo había podido reembolsar sus deudas y costear los gastos precisos para su sustento debido a «los tiempos tan calamitosos», lo que había sido público en México y otras ciudades del virreinato, situación a la que atribuyó el no tener caudal alguno ${ }^{27}$.

La incertidumbre que generaba la posibilidad de encontrar los mercados atiborrados de mercancías era uno de los principales problemas que debían afrontar los flotistas. Xabier Lamikiz analizó la correspondencia de Pedro Munárriz, un navarro

24. Citado en Bernal, 1992: 224.

25. AGI, México, 41, N. 24. año 1665.

26. «6o. Cabezón alcabalatorio», en Documentos, 1945: 136, 163.

27. AGNCM, notario 379, Baltazar Morantes, vol. 2512, año de 1681.

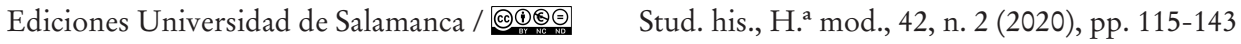


establecido en Cádiz, que en 1699 viajó como cargador en la flota a Nueva España. El comerciante se instaló en la casa de un amigo comerciante vecino de la ciudad de Puebla, en donde realizó sus contrataciones por cerca de dos años, hasta que regresó el convoy a Cádiz. Desde Puebla negoció en otros espacios mediante el apoyo de una red de comerciantes establecidos en los principales núcleos mercantiles del interior y de los peninsulares que se internaron en el virreinato. El protagonista y sus compañeros flotistas enfrentaron grandes dificultades para vender, debido a que el virreinato estaba bien abastecido de mercancías y a la falta de circulante. El problema se agravó en 1700, cuando el arribo de la nao de China al puerto de Acapulco «congeló» las ventas. No obstante, los castellanos tenían el alivio de las compras que realizaban los peruleros, ya que esperaban la llegada de tres embarcaciones procedentes del Perú para que aumentara la demanda. Uno de los mayores aprietos que enfrentó Munárriz fue el cobro de las deudas por las negociaciones que había realizado los años anteriores. El cargador comprobó que las ventas se empezaron a agilizar mucho tiempo después de la llegada de la flota, cuando se difundió la noticia de su próxima partida. Entonces, los castellanos tuvieron que rebajar los precios (Lamikiz, 2011: 43-44). Como había sucedido en años pasados, algunos de los flotista tuvieron que permanecer en Nueva España para dar salida a los bienes que no habían podido vender. Estos solían quedarse a cargo de las ventas de las mercancías de los compañeros que tenían que retornar a la Península.

Los mercados de Nueva España eran muy diversos, por lo que la experiencia de los cargadores y comisionistas españoles variaba mucho. Algunos flotistas tenían negocios con tratantes de plata del consulado y con vecinos de México que se distinguían por su poder político, por lo que su situación contrasta con la anterior. Incluso, había quienes se quedaban a residir en el virreinato de manera permanente, como el caso que veremos a continuación.

\section{LA INTEGRACIÓN DE LOS CARGADORES AL CONSULADO DE MÉXICO}

La historiografía sobre los miembros del cuerpo mercantil de Nueva España ha demostrado que la mayoría procedía de los reinos de Castilla, principalmente de las provincias de vascos y montañeses. Como explicó Brading, y se ha visto en los casos de los mercaderes de plata del periodo que abordamos, éstos llamaban a sus jóvenes sobrinos para que viajaran a México y se incorporaran a sus empresas. Luego de trabajar con empeño y conocer el negocio, algunos se independizaban con el apoyo de la familia y los paisanos. Mientras que los más afortunados se casaban con sus primas y se hacían cargo del negocio cuando moría el tío (Brading, 1975: 149-159; Valle Pavón, 2011: 576-577). Sin embargo, este no era el único origen de los miembros del consulado de México, la corporación también se nutría de los

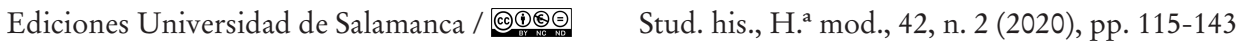


cargadores establecidos en Andalucía que llegaban en las flotas. Tal fue el caso de Francisco Canales Gazio, originario de la villa de Neus, en Tarragona, Cataluña, y residente de Sevilla, quien, luego de trabajar como factor durante varios años, se estableció en la ciudad de México, se vinculó con prominentes miembros del consulado, escaló en la jerarquía social y llegó a desempeñar el oficio de cónsul en el tribunal mercantil.

En 1686, siendo cargador de los reinos de Castilla, con residencia en la ciudad de México, Canales Gazio declaró tener en su poder cerca de 28.800 pesos de los bienes que habían quedado luego de la muerte del licenciado Juan Sáenz Moreno, que había sido oidor de la Audiencia de México, los cuales tomó prestados a su viuda $^{28}$. Es muy probable que el mercader se hubiera asociado con el oidor, que al parecer era originario de Sevilla ${ }^{29}$, para encubrirlo en la realización de actividades comerciales, en las que los funcionarios de alto nivel tenían prohibido participar.

Don Francisco había operado como cargador en la Carrera de Indias varios años antes. En junio de 1673 pidió licencia para embarcarse como consignatario en la flota que iría a Nueva España. Para darle la autorización solicitada, las autoridades de la Casa de contratación consultaron los autos sobre la condena que se le había impuesto en la «visita y residencia» que se le había tomado como maestre de plata del galeón San Felipe, capitana de refuerzo de la flota que había retornado de Veracruz en 1671. Es posible que en dicho navío se haya encontrado plata fuera de registro, porque se impuso a don Francisco el pago de 1.000 pesos de plata y se le prohibió embarcarse en el convoy que ese mismo año partiría al virreinato septentrional. Asimismo, le exigieron el pago de una fianza de 1.000 ducados de plata con el fin de asegurar que volvería en la misma flota a dar cuenta a los dueños de las mercaderías que llevaba como factor. El fiador fue Juan Pérez Caro, residente de Sevilla notoriamente abonado, quien había cargado mercancías en la flota por su cuenta y riesgo, que se entregarían en Veracruz a Canales Gazio, que era su encomendero. Don Francisco tuvo que presentar dos testigos, un vecino de Madrid, estante en Cádiz, y un negociante gaditano. Ambos aseguraron que los padres del interfecto eran cristianos viejos, que tenía 38 años, era soltero y no sujeto a matrimonio. Solo entonces se le dio despacho para embarcarse en la flota que partió en julio de $1673^{30}$.

En 1675 Canales Gazio volvió a hacer la travesía en la flota de Nueva España como comisionista del mismo Pérez Caro, para beneficiar mercancías europeas.

28. Obligación de pago. México, 4 de diciembre de 1686. AGNCM, Juan de Azores, notario 8, vol. 27; Testamento, AGNCM, notario 379, Baltazar Morantes, vol. 2522, Año de 1691.

29. La hija del oidor estaba casada y residía en Sevilla. Además, el oidor dejó un legado a tres hermanos vecinos de la misma ciudad. AGNCM, notario 8, Juan de Azores, vol. 28, Años de 1688 y 1689.

30. AGI, Contratación, 5439, N. 144, Año 1673.

Ediciones Universidad de Salamanca / @@@ Stud. his., H. ${ }^{a}$ mod., 42, n. 2 (2020), pp. 115-143 


\section{GUILLERMINA DEL VALLE PAVÓN \\ CONTRABANDO, NEGOCIOS Y DISCORDIAS ENTRE LOS MERCADERES DE MÉXICO Y LOS CARGADORES PENINSULARES, 1670-1711}

Luego de haber realizado varias expediciones como encomendero, don Francisco debió haber acumulado un caudal considerable, ya que en 1678 viajó a Tierra Firme en calidad de cargador para comerciar bienes de su propiedad. Para entonces empezaba a decaer la feria de Portobelo, de modo que, en 1680, 1682 y 1684 se embarcó en la flota de Nueva España, nuevamente como consignatario de Pérez Caro, y posiblemente de otros cargadores, así como para negociar mercaderías por su propia cuenta ${ }^{31}$.

En la ciudad de México, Canales Gazio se vinculó con algunos de los miembros más destacados del consulado, lo que le permitió hacer inversiones considerables. En 1684, formó compañía con Alonso Dávalos Bracamonte y con otros dos comerciantes, uno flotista y otro vecino de México, para el desagüe, labor y beneficio de una mina en el real del Monte, jurisdicción de Pachuca. De los 20.000 pesos que invirtieron para empezar a explotar la mina, don Francisco colocó 8.000 pesos y los otros tres socios 12.000 pesos $^{32}$. Entonces, uno de los mayores problemas que enfrentaban los productores de plata era la escasez del mercurio, que permitía beneficiar los minerales de baja ley. En 1686 y 1687 don Francisco y Dávalos Bracamonte hicieron un contrato con Benito de Novoa Salgado, oidor de la audiencia de México, para comprar 300 quintales del metal líquido que se encontraban en las reales cajas de Guatemala sin utilizar, y conducirlos al mencionado real para beneficiar sus platas ${ }^{33}$. Novoa Salgado había sido oidor en Guatemala, de modo que es factible que los mercaderes en cuestión se hubieran vinculado con él, por su participación en el tráfico ilegal con los puertos de Guayaquil y el Callao, en el que las radas guatemaltecas de Realejo y Sonsonate eran escalas importantes (Bonialian, 2016). También con el afán de lucrar, Canales Gazio otorgaba dinero a crédito, cuando menos desde 1687, en ocasiones de manera leonina ${ }^{34}$, al tiempo que recibía préstamos en mejores condiciones ${ }^{35}$.

Canales Gazio tuvo éxito en los negocios y supo relacionarse con los miembros de la élite de la ciudad de México, lo que le permitió ascender rápidamente en la

31. AGI, Contratación, 5440, N.2, R. 148. Año 1675; Contratación 5443, N.2, R.36 Año 1680 y Contratación 5445, N. 1, R. 25 Año 1682.

32. En los documentos notariales de México, don Fracisco modificó su apellido a Canales Gazio. AGNCM, notario 379, Baltazar Morantes, vol. 2517, Año de 1686.

33. AGNCM, notario 120, José Esteban de Campos, vol. 779, 1686, 1687.

34. En dicho año, Canales Gazio prestó 2.943 pesos a un comerciante que tenía un cajón en la Plaza Mayor de la ciudad de México. En el contrato se estableció que el cajonero debía reembolsarle 30 pesos cada semana, y en caso de que pasaran tres semanas consecutivas sin haberlo hecho se pasaría mandamiento de ejecución contra su persona y bienes por toda la cantidad que debiera. Obligación de pago. AGNCM, notario 379, Baltazar Morantes, vol. 2519, Año de 1688.

35. Obligación de pago, México, 7 de febrero de 1690. AGNCM, notario 379, Baltazar Morantes, vol. 2521, Año de 1690. 
escala social. En 1687, a la edad de 52 años, se casó con Doña Juana Villaseñor Coria y Lomelí, una acaudalada viuda y compró unas casas principales ${ }^{36}$. Poco después fue electo cónsul del Tribunal mercantil para el bienio 1688-1689. En el segundo año fue votado como cónsul Dávalos Bracamontes, quien desempeñó dicho ministerio hasta $1691^{37}$. Es posible que en el nombramiento de ambos mercaderes haya influido el virrey conde de Galve, con quien establecieron vínculos estrechos, según veremos más adelante. También es factible que por ser representante del cuerpo mercantil, por tener relaciones con el virrey y la oligarquía de mercaderes, en el mismo año de 1688, Canales Gazio fue invitado a formar parte de la mesa de gobierno de la Archicofradía de Nuestra Señora del Rosario, que, en su mayoría estaba formada por los principales mercaderes consulares. En los cinco años que fue diputado, influyó para que se canalizaran parte de los caudales que administraba dicha congregación al banco de plata de Luis Sánchez de Tagle, lo que debió haber reforzado su vínculo con el poderoso mercader ${ }^{38}$. En el bienio 1690-1691 también colaboró como diputado de la mesa de la Archicofradía del Santísimo Sacramento de la Catedral, formada por destacados nobles y caballeros. Desde esta posición, don Francisco influyó para que la archicofradía destinara una de las dotes de las obras pías que administraba a la esposa huérfana de uno de los comerciantes a los que abastecía azúcar y cacao de Guayaquil, lo que reforzó su vínculo clientelar ${ }^{39}$. En ambas congregaciones, Canales Gazio confraternizó con los personajes más prominentes y acaudalados de la capital del virreinato, aun cuando fue nombrado caballero de la orden de Calatrava hasta 1692. A la ceremonia de investidura asistieron otros ilustres caballeros de las órdenes militares, entre los que se destacan los mercaderes Luis Sánchez de Tagle, Domingo de Retes, Antonio Fernández Jubera y Domingo Larrea, quienes, al igual que él, habían sido ministros del tribunal mercantil, lo que pone de manifiesto que entre ellos había vínculos de negocios y amistad ${ }^{40}$.

Presumimos que Canales Gazio estableció una relación interpersonal con el conde de Galve, ya que brindó importante apoyo financiero a Fernando Manuel de Bustamante y Bustillo, que era «gentilhombre» del virrey. Bustamante y Bustillo, quien pertenecía a la más rancia nobleza de Castilla y tenía gran ascendencia en la corte de Madrid, pretendía que el monarca le hiciera merced del gobierno de Yucatán y las provincias de Campeche. Para ello, en 1690 dio poder a su tío Manuel García de Bustamante, que era el secretario del marqués de los Vélez, quien detento un

36. Carta de dote. AGNCM, notario 379, Baltazar Morantes, vol. 2518, Año de 1687.

37. Sobre las elecciones de los miembros del Tribunal mercantil (Valle Pavón, 2003: 41-45).

38. AGNCM, notario 741, Juan de Zearreta, vol. 5240, año 1680; vol. 5243, años 16841687; vol. 5244, años 1688 y 1689; vol. 5245, años 169.

39. México, 30 de enero a 1694. AGNCM, notario 120, José Esteban de Campos, vol. 780, Año de 1694.

40. AGNCM, notario 120, José Esteban de Campos, vol. 780, Años de 1692-1695.

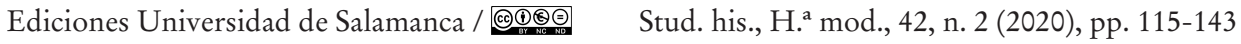




\section{GUILLERMINA DEL VALLE PAVÓN \\ CONTRABANDO, NEGOCIOS Y DISCORDIAS ENTRE LOS MERCADERES DE MÉXICO Y LOS CARGADORES PENINSULARES, 1670-1711}

enorme poder como Presidente del Consejo de Indias, entre diciembre de 1687 y septiembre de 1693; así como a otros dos influyentes personajes, a quienes encargó que pagaran 26.000 pesos por la mencionada gubernatura, no de manera futura, ni "para ningún otro oficio de gobierno» ${ }^{41}$. Dieciséis acaudalados negociantes de la ciudad de México, entre los que se encontraba Canales Gazio, se constituyeron en «fiadores y principales pagadores» de Bustamante y Bustillo, y como tales, se comprometieron a pagar a las personas que en Castilla adelantaran la mencionada suma y los intereses que generara. El plazo para el reembolso se estableció para cuando llegaran los recibos que debían enviarse en los primeros navíos que salieran con destino al puerto de Veracruz y de éste se remitieran a la capital del virreinato ${ }^{42}$. Bustamante y Bustillo no logró conseguir dicho nombramiento, pero, unos meses después, el conde de Galve lo designó gobernador de la provincia de Tlaxcala ${ }^{43}$.

Dada la la relación que el virrey tenía con Canales Gazio y Dávalos Bracamonte, es probable que se valiera de ellos para comerciar en Perú, de manera subrepticia, los géneros que abastecían la flota del Atlántico y el galeón de Manila. Asimismo, es factible que don Francisco realizara contrataciones en Manila, dado que tenía vínculos con los representantes del gobernador de Filipinas, Juan de Vargas Hurtado ${ }^{44}$, quien, en 1687 fue depuesto, entre otras razones, por participar en el comercio ilícito (Picazo Muntaner, 2011: 140-152). Canales Gazio y Dávalos Bracamonte se asociaron para comerciar con los peruanos, negocio que rendía ganancias muy elevadas, pero implicaba grandes riesgos. Al inicio de la década de 1702 Dávalos Bracamonte, tuvo que dar un poder, en su nombre y como albacea del difunto don Francisco, a tres comerciantes que partían al Perú, para que tomaran cuentas y cobraran 20.600 pesos que les adeudaba un capitán de navío. Cuatro años después, no había alcanzado su objetivo, ya que la audiencia de México tuvo que librar un exhorto al consulado de Lima para que se saldara la mencionada deuda ${ }^{45}$.

41. De acuerdo con Francisco Andújar, en el periodo en que el marqués de los Vélez estuvo a la cabeza del Consjo de Indias, se intensificaron las ventas de cargos en Hispanoamérica, lo que fue muy lucrativo para el marqués, su esposa y su secretario (Andújar Castillo, 2008: 286-293 y en prensa).

42. Poderes. Mexico, 4 de febrero de 1690. AGNCM, notario 379, Baltazar Morantes, vol. 2521, Año de 1690. Agradezco a Francisco Andújar el tiempo que dedicó a ayudarme a comprender estos crípticos documentos.

43. Relación de Méritos y servicios de Fernando Manuel Bustamante y Bustillo. AGI, Indiferente General 133, N. 105, año de 1694 y 1699.

44. En 1684, poco antes de partir rumbo a Manila, Vargas Hurtado había recibido en Sevilla un préstamo por 3.000 pesos del cargador Juan Pérez Caso, a quien Canales Gazio servía como consignatario. En 1689 Canales Gazio, como apoderado de Pérez Caso, recibió el pago de dicha suma. AGNCM, notario 379, Baltazar Morantes, vol. 2520, Año de 1689.

45. Canales Gazio había muerto en 1694. Poder general. AGNCM, notario 692, Francisco de Valdés, vol. 4696, Año 1702. Exhorto de la audiencia de México al Consulado del Perú, 1706, (Garritz, 1993, núm. 44.8). 
Concluida la guerra de Sucesión, las autoridades reales se esforzaron por regularizar la carrera de Indias con el propósito de generar mayores recursos fiscales y neutralizar el contrabando. El conflicto entre los mercaderes mexicanos y andaluces se agudizó con la entrada legal de los ingleses en el mercado novohispano. El poder naval y militar adquirido por Gran Bretaña durante la guerra se puso de manifiesto cuando logró desplazar a los franceses de las concesiones que les había otorgado Felipe V, a raíz de la unión de las dos coronas. En el «Tratado de navegación y comercio» de Utrecht, de 1713, el monarca se comprometió a mantener el sistema de monopolio bipolar, concedió a la Compañía de los Mares del Sur el asiento para el abasto de esclavos a las posesiones hispanoamericanas, y permiso para enviar dos buques con 500 toneladas de mercancías para comerciar en Veracruz y Portobelo a la llegada de las flotas, libres del pago de derechos.

\section{CONCLUSIONES}

La participación de los mercaderes de la ciudad de México en el comercio Atlántico tuvo varias modalidades: fueron encomenderos de las casas de comercio de Sevilla y Cádiz, compradores en las Ferias de flotas e invirtieron en el contrabando que practicaban los enemigos de la corona. Esto fue posible, por una parte, por su capacidad para intercambiar la plata, gravada y sin quintar, en los mercados legales y clandestinos. Y por otra, por la articulación de tramas de negocios en las que integraban a los virreyes, los cargadores castellanos y las autoridades de Veracruz, entre otros, además de contar con la complicidad de la oficialidad de la carrera de Indias. Algunos de estos actores económicos se vieron beneficiados de los vínculos interpersonales que establecieron con los virreyes, a cuyo nombre realizaban contrataciones. Por su parte, los representantes del soberano se valían del enorme poder que detentaban para su enriquecimiento personal, lo que iba en detrimento de la autoridad real y, en particular, de la real hacienda. Los mercaderes garantizaban la complicidad de los castellanos, oficiales reales y autoridades del puerto de Veracruz, a través de diversas estrategias, como el establecimiento de redes familiares, el otorgamiento de préstamos para la compra de sus cargos, así como para pagar las fianzas requeridas y realizar negocios personales. Los miembros del consulado de Sevilla y, probablemente, las casas extranjeras establecidas en la misma ciudad realizaban prácticas similares con los oficiales de la Armada y la Carrera de Indias, quienes, al recibir financiamiento para la compra de sus nombramientos, quedaban involucrados en los negocios de sus acreedores.

El contrabando, que parece haber sido el contrapeso del monopolio, fue favorecido por los cambios institucionales que la monarquía introdujo en la financiación de la Carrera de Indias, presionada por los gastos bélicos y diplomáticos que tenía que afrontar. El fortalecimiento de las naciones manufactureras en Europa, unido a las 
necesidades financieras de la corona y los intereses de la Universidad de cargadores de Indias, condujeron a la modificación de las normas y prácticas en el tráfico de las flotas. El comercio ilícito que se realizaba a gran escala a través de los convoyes y del comercio intérlope que practicaban los rivales de la corona desde sus posesiones en las Antillas, ocasionó una sangría de plata creciente para el Imperio hispánico.

Los tratantes de plata de la ciudad de México y los cargadores peninsulares se beneficiaron del monopolio de la Carrera de Indias, en el que participaban de manera legal e ilícita. El contrabando les permitía traficar con mercancías de bajos precios y evadir el pago de derechos reales. Mediante el establecimiento de encomiendas con los peninsulares, la participación en el comercio intérlope de las Antillas y el tráfico de bienes orientales, los mercaderes de México abastecían los mercados del virreinato, las posesiones de las Antillas, Guatemala y Panamá, así como los puertos de la Mar del Sur. Estos espacios también estaban abiertos a la circulación clandestina. Así, mediante el tejido de redes de negocios, complicidad y connivencia, la capital de Nueva España se transformó en el centro de la articulación global de los mercados del Atlántico y el Pacífico.

Ante el notable incremento que presentó el abasto de bienes europeos y asiáticos en el periodo que abordamos, los consulados de México y Sevilla consiguieron espaciar las flotas para mantener una oferta limitada, con el fin de obtener altos márgenes de ganancias. Sin embargo, la concurrencia de mercancías dificultó a los cargadores flotistas vender a precios elevados y propició que entraran en conflicto con los mercaderes de México, que se confabulaban para conseguir que los redujeran. Esto era posible porque tenían a su favor, tanto el control de la mayor parte de la plata, como el abasto de los géneros asiáticos y europeos que ingresaban mediante el contrabando, además de la posibilidad de almacenarlos, para comprar o vender en los momentos más oportunos. Aun cuando los representantes de los peninsulares consiguieron mantener oculto el contenido de sus cargazones, tenían dificultades para imponer altos precios, como habían hecho desde el inicio de la Carrera de Indias.

Finalmente, nos preguntamos: ¿cómo podemos comprender la desobediencia de la normatividad comercial y la tolerancia del contrabando por parte de la monarquía? tales prácticas pueden explicarse debido a la venalidad de la mayor parte de los nombramientos de la administración real, incluyendo los de virreyes y gobernadores, quienes, al igual que los oficiales de la real hacienda, se esforzaban por recuperar las inversiones realizadas, pagar a sus acreedores y, sobre todo, lucrar mediante el ejercicio de sus cargos. Es probable que, por el hecho de haber pagado por sus nombramientos, se sintieran justificados para cometer todo tipo de ilícitos, así como sucedía con quienes recibían el perdón divino mediante la compra de la «bula de contrabando». Estas prácticas debilitaron a la corona y fortalecieron a la oligarquía mercantil de la ciudad de México, que cada vez operaba con mayor autonomía y sin apego a la normatividad real. No obstante, también habría que

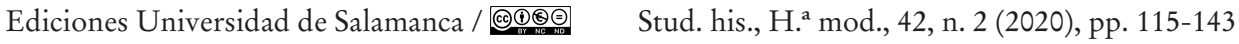




\section{GUILLERMINA DEL VALLE PAVÓN \\ CONTRABANDO, NEGOCIOS Y DISCORDIAS ENTRE LOS MERCADERES DE MÉXICO \\ Y LOS CARGADORES PENINSULARES, 1670-1711}

considerar que el contrabando dinamizaba la actividad productiva y el comercio en Hispanoamérica, lo que permitía al real fisco obtener ingresos por concepto de la explotación de plata y las actividades que dicha producción dinamizaba, así como por la recaudación de las alcabalas, que gravaba la circulación interna. Por otra parte, el tráfico clandestino que se practicaba en las carreras de Indias y Filipinas, así como en el comercio interamericano, son muestra de la inconformidad de los súbditos americanos con las restricciones que imponía la política comercial del Imperio para obtener la mayor rentabilidad posible.

\section{BIBLIOGRAFÍA}

Andújar Castillo, F. (en prensa). «Corrupción y patronazgo en la España de Carlos II. Una primera aproximación».

Andújar Castillo, F. (2019). Controlar sin reformar: la corrupción de los virreyes de Indias en el siglo XVII, Memoria y Civilización. Anuario de Historia, pp. 317-342.

Andújar Castillo, F. (2018). Marinos o mercaderes. Sobre los mandos de las armadas de la Carrera de Indias en el reinado de Carlos II. En J. J. Iglesias Rodríguez, J. J. García Bernal y J. M. Díaz Blanco (eds.) Andalucía en el mundo atlántico moderno. Ciudades y Redes. Madrid: Sílex, pp. 239-261.

Andújar Castillo, F. (2016) Los generales y almirantes de la Carrera de Indias en el último tercio del siglo XVII). En J. J. Iglesias Rodríguez. y J. J. García Bernal (eds.), Andalucía y el mundo atlántico moderno. Agentes y escenarios. Madrid: Sílex, pp. 265-286.

Andújar Castillo, F. (2008). Necesidad y venalidad. España e Indias, 1704-1711. Madrid: Centro de Estudios Políticos y Constitucionales.

Bakewell, P. (1976). Minería y sociedad en el México Colonial. Zacatecas (1546-1700). México: Fondo de Cultura Económica.

Bernal, M. A. (1992). La financiación de la Carrera de Indias (1492-1824). Dinero y crédito en el comercio colonial español con América. Sevilla: Fundación El Monte.

Bertrand, M. (2011). Grandeza y miseria del oficio. Los oficiales de la Real Hacienda de la Nueva España, siglos XVII y XVIII. México: Fondo de Cultura Económica.

Bonialian, M. (2016). El Galeón de Manila y el comercio entre Filipinas, México y Perú en la época colonial. En L. G. Morales (coord.), Tornaviaje: la Nao de China y el Barroco en México, 1565-1815 (pp. 38-42). Madrid: Ediciones El Viso.

Brading, D. (1975). Mineros y comerciantes en el México borbónico (1763-1810). México: Fondo de Cultura Económica.

Bustos Rodríguez, M. (2005). Cádiz en el sistema Atlántico. La ciudad, sus comerciantes y la actividad mercantil (1650-1830). Madrid: Sílex Ediciones, Universidad de Cádiz.

Delgado Rivas, J. M. (2007). Dinámicas imperiales [1650-1796]. España, América y Europa en el cambio institucional del sistema colonial español. Barcelona: Ediciones Bellaterra.

Díaz Blanco, J. M. (2012). Así trocaste tu gloria. Guerra y comercio colonial en la España del siglo XVII. Valladolid: Madrid, Instituto Universitario Simancas / Editorial Marcial Pons. 


\section{GUILLERMINA DEL VALLE PAVÓN \\ CONTRABANDO, NEGOCIOS Y DISCORDIAS ENTRE LOS MERCADERES DE MÉXICO \\ Y LOS CARGADORES PENINSULARES, 1670-1711}

Díaz Blanco, J. M. (2015). Sobre las armadas de Indias: la práctica del 'beneficio y la crisis de la Avería (1660-1700)'. Gladius. Estudios sobre armas antiguas, arte militar y vida cultural entre Oriente y Occidente, 35, pp. 117-138.

Díaz Blanco, J. M. (2018). La Carrera de Indias (1650-1700): Continuidades, rupturas, replanteamientos, e-Spania, 29.

Documentos relativos al arrendamiento del impuesto o renta de alcabalas de la ciudad de México y distritos circundantes. (1945). México: Archivo Histórico de Hacienda, México, Secretaría de Hacienda y Crédito Público. Dirección de Estudios Financieros.

García de León, A. (2011). Tierra adentro, mar en fuera. El puerto de Veracruz y su litoral a Sotavento, 1519-1821. México: Fondo de Cultura Económica; Gobierno del Estado de Veracruz; Universidad Veracruzana.

García-Fuentes, L. (1980). El comercio español con América, 1650-1700. Sevilla: Excma. Diputación Provincial de Sevilla / Escuela de Estudios Hispanoamericanos, CSIC.

Garritz, A. (1993). Guía del Archivo Moctezuma-Miravalle. México: Universidad Nacional Autónoma de México, 172 p.

Girard, A. (2006). El comercio francés en Sevilla y Cádiz en tiempos de los Habsburgo. Sevilla: Renacimiento.

González González, E. y Gutiérrez Rodríguez , V. (2002). 'En tiempos tan urgentes’. Informe secreto de Palafox al rey sobre el Estado de la Nueva España (1641). En J. Pascual Buxó (ed.), Juan de Palafox y Mendoza. Imagen y discurso de la cultura novohispana (pp. 71-92). México: Universidad Nacional Autónoma de México.

Goyas Mejía, R. (2011). Notas sobre la vida de Pedro Sánchez de Tagle. Estudios de Historia Novohispana, 45, pp. 47-80.

Guijo, G. M. de (1952). Diario 1648-1664, México, Editorial Porrúa, t. I.

Gutiérrez Lorenzo, M. P. (1993). De la Corte de Castilla al virreinato de México: El conde de Galve (1653-1697). Madrid: Diputación Provincial de Guadalajara.

Hoberman, L. (1991). Mexico's merchant elite, 1590-1660. Silver, state and society. Durham: Duke University Press.

Hoberman, L. (1998). El crédito colonial y el sector minero en el siglo XVII: aportación del mercader de plata a la economía colonial. En P. Martínez, P. y G. del Valle Pavón (coords.), El crédito en Nueva España (pp. 61-82). México: Instituto Mora, El Colegio de Michoacán, El Colegio de México, Instituto Investigaciones Históricas, UNAM.

Huerta, M. T. (2007). Redes mercantiles en torno a la plata en el norte minero novohispano. Segunda mitad del siglo XVII. En A. Ibarra A. y G. del Valle Pavón (coord.), Redes sociales e instituciones comerciales en el Imperio Español, siglos XVII a XIX (pp. 85-116). México: Universidad Nacional Autónoma de México, Facultad de Economía; Instituto de Investigaciones Dr. José María Luis Mora.

Lang, M. F. (1977). El monopolio estatal del mercurio en el México colonial (1550-1710). México: Fondo de Cultura Económica.

Lamikiz, X. (2011). Flotistas en la Nueva España: diseminación espacial y negocios de los intermediarios del comercio transatlántico, 1670-1702. Colonial Latin American Review, 20(1), pp. 9-33.

Ediciones Universidad de Salamanca / @®@@ Stud. his., H. ${ }^{a}$ mod., 42, n. 2 (2020), pp. 115-143 


\section{GUILLERMINA DEL VALLE PAVÓN \\ CONTRABANDO, NEGOCIOS Y DISCORDIAS ENTRE LOS MERCADERES DE MÉXICO \\ Y LOS CARGADORES PENINSULARES, 1670-1711}

Macleod, M. J. (1990). España y América: el comercio Atlántico, 1492-1720. En L. Bethell (ed.), Historia de América Latina. 2. América Latina colonia: Europa y América en los siglos XVI, XVII, XVIII. Barcelona: Editorial Crítica, v. 2, pp. 45-84.

Martínez Ruiz, J. I. (2011). ¿Cádiz, Jamaica o Londres? La colonia británica de Cádiz y las transformaciones del comercio inglés con la América España (1655-1750). Studia Historica Historia Moderna, 33, pp. 177-202.

Morineau, M. (1985). Incroyables gazettes et trésors merveilleux. Les retorus des trésors américains d'aprés les gazettes hollandaises (XVIe-XVIIIe siécles). Londres: Cambridge University Press. Paris: Editions de la Maison des Sciences de l'Homme.

Navarro García, L. (1979). La secreta condena del virrey Alburquerque por Felipe V. En Homenaje al Dr. Muro Orejón (v. 1, pp. 200-214). Sevilla: Facultad de Filosofía y Letras; Universidad de Sevilla.

Oliva Melgar, J. M. (2005). La metrópoli sin territorio. ¿Crisis del comercio de Indias en el siglo XVII o pérdida del control del monopolio? En C. Martínez Shaw y J. M. Oliva Melgar M. (eds.), El sistema Atlántico Español (Siglos XVII-XIX) (pp. 19-73)., Madrid: Marcial Pons, Ediciones de historia.

Pérez-Mallaína, P. E. (1986). «Estudio, transcripción y notas» a Francisco de Seijas y Lobera, Gobierno militar y político del Reino Imperial de la Nueva España (1702) (pp. 7-177). México: Universidad Nacional Autónoma de México.

Picazo Muntaner, A. (2011). Redes invisibles: cooperación y fraude en el comercio de Manila-Acapulco. Anales del Museo de América, 19, pp. 140-152.

Prakash, O. (2001). Global Precious Metal Flows and India, 1500-1750». En J. McGuire, P. Bertola y P. Reeves (coords.), Evolution of the World Ec2001, Economy, Precious Metals and India. Nueva York: Oxford University Press.

Romano, R. (2004). Mecanismo y elementos del sistema económico colonial americano. Siglos XVI-XVIII. México: Fondo de Cultura Económica, Fideicomiso Historia de las Américas.

Rosenmüller, Ch. (2008). Patrons, partisans and palace intrigues. The Court society of colonial Mexico 1702-1710, Calgary. University of Calgary Press.

Sanchíz, J. y Conde, J. I. (2005). La familia Monterde y Antillón en Nueva España. Reconstrucción genealógica (Segunda parte). Estudios de Historia Novohispana, 33, pp. 97-172.

Seijas y Lobera, F. (1986). Gobierno militar y político del Reino Imperial de la Nueva España (1702). México: Universidad Nacional Autónoma de México.

Serrano Hernández, S. (2018). La golosina del oro. La producción de metales preciosos en San Luis Potosi y su circulación global en mercados orientales y occidentales durante el siglo XVII. México: El Colegio de San Luis, El Colegio de Michoacán, Instituto de Investigaciones Dr. José María Luis Mora.

Stein, S. J. y B. H. Stein (2002). Plata, comercio y guerra. España y América en la formación de la Europa moderna. Barcelona: Editorial Crítica.

Torre Villar, E. (coord.). (1991). Instrucciones y memorias de los virreyes novohispanos. México: Editorial Porrúa, t. II.

Ediciones Universidad de Salamanca / @@@ Stud. his., H. ${ }^{a}$ mod., 42, n. 2 (2020), pp. 115-143 


\section{GUILLERMINA DEL VALLE PAVÓN \\ CONTRABANDO, NEGOCIOS Y DISCORDIAS ENTRE LOS MERCADERES DE MÉXICO \\ Y LOS CARGADORES PENINSULARES, 1670-1711}

Torre Villar, E. (1967). El contrabando y el comercio exterior en la Nueva España. México: Colección de documentos para la historia del comercio exerior de México, Segunda Serie.

Valle Pavón, G. (2020). 'Lágrimas y maldiciones'. La intermediación financiera del consulado de México al servicio de la Monarquía Hispánica, 1680-1708. En G. del Valle Pavón (coord.), Negociación, lágrimas y maldiciones. La fiscalidad extraordinaria en la monarquia hispánica, 1620-1814 (pp. 131-16). México: Instituto de Investigaciones Doctor José María Luis Mora.

Valle Pavón, G. (2011). Bases del poder de los mercaderes de plata de la ciudad de México. Redes, venalidad, consulado y casa de moneda a fines del siglo XVII. Anuario de Estudios Americanos, 68(2), 565-598.

Valle Pavón, G. (2006). Negocios y redes familiares y sociales de los Sánchez de Tagle, mercaderes de plata de México (1660-1724). En R. Domínguez Martín y M. Cerutti Pignat (eds.), De la Colonia a la globalización. Empresarios cántabros en México (pp. 15-45). Santander: Servicio de Publicaciones de la Universidad de Cantabria.

Valle Pavón, G. (2003). Gestión del derecho de alcabalas y conflictos por la representación corporativa: la transformación de la normatividad electoral del consulado de México en el siglo XVII. En B. Hausberger B. y A. Ibarra (coords.), Comercio y poder en América colonial: los consulados de comercio siglos XVIII y XIX. Elites comerciales, instituciones corporativas y gestión del cambio económico colonial (pp. 41-72).. Madrid: Iberoamericana; Frankfurt, Vervuert Verlag; México, Instituto de Investigaciones Dr. José María Luis Mora.

Walker, G. J. (1979). Política española y comercio colonial, 1700-1789. Barcelona: Editorial Ariel.

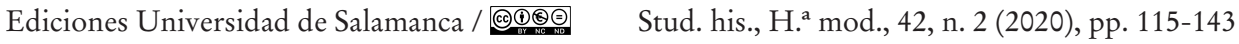


